\title{
The Control of Insulin Receptors in the New Zealand Obese Mouse
}

\author{
D. Baxter and N.R. Lazarus \\ Diabetes Research Laboratory, the Wellcome Foundation Limited, Dartford. Kent, England
}

Received: November 4, 1974, and in revised form: April 16, 1975

\begin{abstract}
Summary. Insulin receptor concentrations in liver plasma membranes of New Zealand Obese (NZO) mice have been studied. When NZO mice were implanted with normal islets of Langerhans their blood glucose and plasma insulin declined. When the implanted islets were removed these changes were reversed and the mice reverted to their insulin resistant state. Changes were observed in the binding of ${ }^{125} \mathrm{I}$-insulin to liver plasma membranes of implanted NZO mice. Binding increased when the plasma insulin was
\end{abstract}

decreased and conversely insulin binding decreased when the plasma insulin levels became elevated. The increased insulin binding was not accompanied by any changes in the affinity of NZO liver receptors for insulin.

Key words: Receptor, insulin, liver, plasma membrane, NZO mice, implantation.
New Zealand Obese (NZO) mice are characterised by hyperinsulinaemia, hyperglycaemia, obesity and insulin resistance [1]. Gates et al. [2, 3] have shown that when islets from normal albino laboratory mice are implanted into NZO mice there is a reduction in the blood glucose, plasma insulin, rate of weight increase and an improvement in glucose tolerance. When the implanted islets are removed the animals revert to their obese, insulin resistant state.

We have previously reported [4] that insulin binding to liver membranes is increased when the insulin and glucose have been reduced and that this increase is lost on reversion. In this study we have attempted to establish the time of onset of the changes in insulin binding with reference to changes in plasma insulin and blood glucose levels.

\section{Materials and Methods}

NZO mice derived from the original stock of Bielschowsky and Bielschowsky [5], were obtained from the Diabetes Research Laboratory, The Wellcome Foundation Limited, Dartford. The normal albino mice were supplied by Evans Animal Supplies, Carshalton, Surrey. All animals were fed on PRD diet (Christopher Hill Group, Poole, Dorset) and tap water. Collagenase was obtained from Worthington Biochemicals, Wembley, Middlesex, $0.45 \mu \mathrm{m}$ pore filters, type EGWP, from Millipore Corporation. Carrier free ${ }^{125} \mathrm{I}$-sodium iodide type IMS 300 was obtained from the Radiochemical Centre, Amersham and beef insulin from Burroughs Wellcome and Company, Dartford, Kent.

Bovine serum albumin Fraction IV and glucose6-phosphate were from Sigma (London) Chemical Company; $5^{\prime}$ adenosine monophosphate, adenosine deaminase and cytochrome $\mathrm{C}$ were from Boehringer Mannheim $\mathrm{GmbH}$ and all other chemicals were from BDH Chemicals Limited, Poole, Dorset.

\section{Methods}

The Implantation of Mice. The precise methods have been described elsewhere [2]. In brief, islets were isolated from normal albino mice by the collagenase technique and 200 islets were implanted intraperitoneally into each mouse using a small implantation chamber constructed from Millipore membranes. The operation was carried out under ether anaesthesia. Blood glucose, plasma insulin and body weights were measured at weekly intervals. Blood samples were obtained by tail bleeding before $10.30 \mathrm{a} . \mathrm{m}$. Glucose was determined by a modification of the Faulkner [6] continuous flow glucose oxidase method and plasma immunoreactive insulin by a double antibody method [7] using ox insulin standard.

Male NZO mice (5-6 weeks old) were implanted with islets from normal albino mice for periods of up to 8 weeks. Mice were sacrified at $3,5,7$ and 8 weeks after implantation of islets and liver plasma membranes prepared. The implanted islets were removed from 30 animals after 6 weeks. Mice from this group were subsequently sacrificed at 2, 4 and 6 
weeks after removal of the implant. At each time point plasma membranes were prepared from the livers of 9-12 mice.

The Preparation of Liver Plasma Membranes. Liver plasma membranes were prepared from freshly excised livers by the method described by Ray [8] for rat liver, except that the number of strokes in the Dounce homogeniser $(0.2 \mathrm{~mm})$ were reduced by half to give.a more gentle homogenisation. Membranes were kept frozen in aliquots at $-70^{\circ} \mathrm{C}$ in a Krebs Ringer phosphate (KRP) buffer. The protein content of the membranes was determined by the method of Lowry et al. [9] after sodium hydroxide digestion, using bovine serum albumin as the standard.

The Preparation of ${ }^{125}$ I-Insulin. Iodinated insulin was prepared from single component beef insulin (Wellcome) and $\mathrm{Na}^{125} \mathrm{I}$ using chloramine $\mathrm{T}$ according

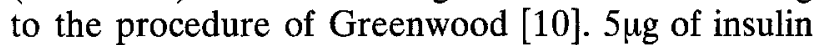
was reacted with $1.5 \mathrm{mCi} \mathrm{Na}{ }^{125} \mathrm{I}$ in borate buffer $\mathrm{pH}$ 8.0. No more than $15 \mathrm{sec}$ exposure to chloramine $\mathrm{T}$ was allowed before terminating the reaction with sodium metabisulphite and separating the product from reactants on a $7 \times 150 \mathrm{~mm}$ column of Sephadex G-25 coarse, equilibrated with $0.2 \mathrm{M}$ borate buffer $\mathrm{pH} 8.0$, $0.16 \mathrm{M} \mathrm{NaCl}, 1 \%$ human serum albumin. This was followed by gel filtration on a $25 \times 400 \mathrm{~mm}$ column of Sephadex G-50 superfine equilibrated with KRP 1\% bovine albumin buffer $\mathrm{pH} 7.4$. Iodinated insulin prepared in this way had an initial specific activity of 1.1 $\mathrm{Ci} / \mu$ mole at a concentration of $35 \mathrm{ng} \mathrm{ml}^{-1}$ when assayed by radioimmunoassay using ${ }^{131} \mathrm{I}$-insulin. The ${ }^{125} \mathrm{I}$ insulin was more than $95 \%$ precipitable by trichloroacetic acid and showed full biological activity on isolated rat fat cells. The ${ }^{125} \mathrm{I}$-insulin was stored in aliquots at $-20^{\circ} \mathrm{C}$ in KRP $1 \%$ albumin, $\mathrm{pH} 7.4$, buffer.

The Binding of ${ }^{125}$ I-Insulin to Liver Membranes. The measurement of ${ }^{125} \mathrm{I}$-insulin binding to liver plasma membranes was carried out at $24^{\circ} \mathrm{C}$ by a method similar to that of Cuatrecasas [11]. Radioactive insulin and liver membranes were incubated for $40 \mathrm{~min}$ in a final volume of $300 \mu \mathrm{l}$ of Krebs Ringer phosphate buffer, $\mathrm{pH} 7.4$, containing $1 \%$ bovine serum albumin and various concentrations of insulin and membranes as described in the legends to tables and figures. Each sample of membranes, after thawing, was diluted and assayed for protein content prior to use. The assay on each sample was performed in triplicate. After the incubation period the plastic assay tubes were chilled $\left(4^{\circ} \mathrm{C}\right)$ and the membranes collected by filtration on Millipore filters type EGWP and washed four times with approximately $2 \mathrm{ml}$ of $0.1 \%$ albumin $\mathrm{KRP}$ at $4^{\circ} \mathrm{C}$. The filters were counted in a Nuclear Enterprises automatic gamma counter type NE 8312 with an efficiency of $55 \%$. Binding quoted is the specific binding obtained by subtracting the counts due to non-specific binding. Counts bound nonspecifically were defined as those counts not displaced by native insulin at a concentration of $2 \times 10^{-5} \mathrm{M}$.

The Enzyme Marker Assays. All the enzyme marker assays were carried out at $37^{\circ} \mathrm{C} .5^{\prime}$ nucleotidase was determined by the method of Belfield and Goldberg [12] and succinate-cytochrome $\mathrm{C}$ reductase by the method of Fleischer and Fleischer [13] using a recording Gilford spectrophotometer. Glucose-6phosphatase was measured in $90 \mathrm{mM}$ acetate buffer pH 6.0 containing $10 \mathrm{mM}$ glucose- 6 -phosphate. The liberated phosphate was measured by the method of Fiske and Subbarow [14].

Degradation of ${ }^{125}$ I-Insulin by Plasma Membranes. Membranes were incubated with $1 \times 10^{-10} \mathrm{M}{ }^{125} \mathrm{I}-$ insulin as described in the methods for insulin binding. The percentage of ${ }^{125} \mathrm{I}$-insulin remaining after the incubation period was determined by centrifuging the membranes and removing the supernatant. Two methods, gel filtration and precipitation by $5 \%$ trichloroacetic acid (TCA), were used to assess the degradation.

Gel Filtration. $100 \mu \mathrm{l}$ of supernatant was applied to a column $7 \times 220 \mathrm{~mm}$ of G-50 Sephadex equilibrated and run in $1 \%$ albumin KRP buffer. 15 drop fractions were collected directly into scintillation vials and counted for ${ }^{125} \mathrm{I}$. Controls were incubated without membranes and $100 \mu \mathrm{l}$ was applied to the same G-50 Sephadex column. The area of the peaks was determined and the percentage ${ }^{125}$ I-insulin remaining intact calculated.

TCA Precipitation. 50 $\mu \mathrm{l}$ aliquots of supernatant were made up to $500 \mu \mathrm{l}$ with $0.1 \%$ albumin KRP. $500 \mu \mathrm{l}$ of cold $\left(4^{\circ} \mathrm{C}\right) 10 \% \mathrm{w} / \mathrm{v}$ TCA was added and the precipitate collected by centrifugation. The pellet and supernatant were counted for radioactivity.

\section{Results}

\section{The Implantation of Islets}

The blood glucose and plasma insulin of the implanted animals decreased steadily reaching minimal values 6 weeks after implantation as shown in Fig. 1. These values were maintained through the 7 th and 8 th weeks of implantation (data not shown). That these falls reflect a change in insulin resistance was shown by improved tolerance to oral glucose [2]. When the islet implant was removed the blood glucose and plasma insulin began to rise within 1 week and continued to do so over the following 6 weeks, that is, weeks $6-12$ in Fig. 1. The blood glucose and plasma insulin levels 


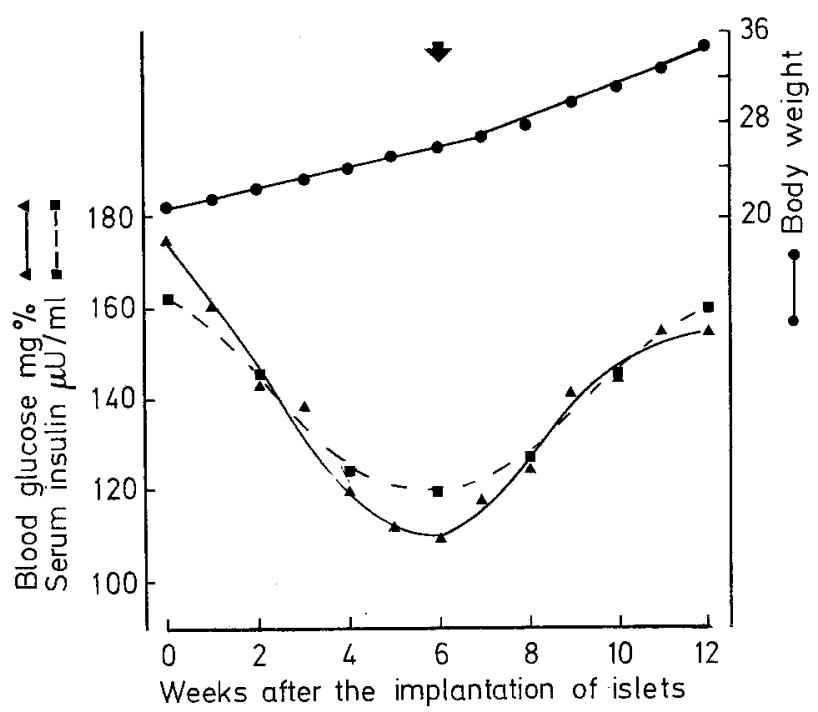

Fig. 1. The changes in body weight, circulating glucose and insulin following the implantation of normal mouse islets into NZO mice. Body weight grams $(\bullet)$, blood glucose $\mathrm{mg} \%(\boldsymbol{\Lambda})$ and plasma insulin $\mu \mathrm{U} \mathrm{ml}^{-1}(\mathbf{D})$ are plotted against time, in weeks, after the implantation of islets. The effect of removing the islets after 6 weeks is also shown. 2, 4 and 6 week values are significantly different from initial, $p<0.01,0.001$ and 0.001 respectively (Student's t-test)

Table 1 a). The specific activity of liver plasma membrane 5 ' nucleotidase following the implantation of islets of Langerhans into NZO mice ( \pm standard deviation)

Implantation period

$\begin{array}{lllllll}\text { before membranes were } & 0 & 3 & 5 & 7 & 8\end{array}$
prepared: weeks

\begin{tabular}{llllll}
\hline $5^{\prime}$ nucleotidase activity & 6.03 & 5.97 & 6.31 & $5.54^{\mathrm{a}}$ & 5.59
\end{tabular}

$\mu \mathrm{moles} / \mathrm{hour} / \mathrm{mg} \quad \pm 0.79 \pm 0.53 \pm 0.79 \pm 0.60 \pm 0.80$

Table 1b). The specific activity of liver plasma membrane 5' nucleotidase at different times following the removal of islets of Langerhans which had been implanted for six weeks into NZO mice ( \pm standard deviation)

Period after the removal of implanted

$\begin{array}{llll}\text { islets before membranes } & 2 & 4 & 6\end{array}$

werc prepared: weeks

\begin{tabular}{llll}
\hline $5^{\prime}$ nucleotidase activity & 6.07 & $7.31^{\mathrm{b}}$ & 6.26 \\
$\mu$ moles/hour/mg & \pm 1.07 & \pm 1.15 & \pm 1.52
\end{tabular}

Significance of the difference of each mean from the mean of all other membranes was calculated by the paired t-test.

${ }^{\mathrm{a}} p<0.05 ;{ }^{\mathrm{b}} p<0.02$

$5^{\prime}$ nucleotidase activity is expressed as $\mu$ moles of $5^{\prime}$ adenosine monophosphate hydrolysed/hour/mg protein. of the untreated control mice increased by $10-15 \%$ of their initial values during the course of the experiment $[2,3]$. Previous experiments $[2,3]$ have shown that NZO mice implanted with empty chambers, NZO islets, or other tissue do not show alleviation of their hyperinsulinaemia and hyperglycaemia.

The rate of weight increase of the mice is also affected. Implanted mice increase their weight at a rate of $0.9 \mathrm{~g} /$ week during the 6 weeks following implantation. This is significantly slower, $p<0.001$, than the control mice which gained weight at $1.5 \mathrm{~g} /$ week. When the implanted islets were removed the rate of weight gain increased to $1.5 \mathrm{~g} / \mathrm{week}$, Fig. 1. The food intake, however, of implanted mice was similar to that of control mice of the same age, $3.6 \mathrm{~g}$ and $3.7 \mathrm{~g} /$ mouse/ day respectively. The water consumption was the same at $3.2 \mathrm{ml} / \mathrm{mouse} /$ day.

\section{The Preparation of Liver Membranes}

The weights of livers ranged from $1.5-2.5 \mathrm{~g}$ and yielded $1.5-2 \mathrm{mg}$ membrane protein/g wet weight of liver. The membranes were homogeneous by phase contrast microscopy and of reproducible purity as was shown by the specific activity of $5^{\prime}$ nucleotidase, succinate-cytochrome $\mathrm{C}$ reductase and glucose-6-phosphatase.

\section{Marker Enzyme Assays}

The specific activity of the membrane $5^{\prime}$ nucleotidase was determined in two separate assays. Two concentrations of membranes were used in each assay to ensure that the rate of reaction was dependent on the amount of enzyme added. The value for each concentration was determined in duplicate. The mean specific activity of $5^{\prime}$ nucleotidase for all the membranes was $6.14 \pm 0.55 \mu \mathrm{moles} /$ hour $/ \mathrm{mg}$ protein. The results for each set of membranes shown in Table $1 \mathrm{a}$ and $1 \mathrm{~b}$ indicate that only two of the membrane preparations deviated significantly from this mean value: those prepared after 7 weeks implantation, and those prepared 4 weeks after the implanted islets had been removed. Succinate-cytochrome Creductase and glucose-6-phosphatase activities were measured in liver membranes obtained from NZO and implanted NZO mice. The specific activity of succinatecytochrome $C$ reductase was $2.4 \pm 0.7$ and $2.5 \pm$ $0.8 \mu \mathrm{moles} / \mathrm{hour} / \mathrm{mg}$ protein respectively for untreated and implanted mice, and the specific activity of glucose-6-phosphatase was $1.3 \pm 0.4$ and $1.3 \pm$ $0.3 \mu \mathrm{moles} / \mathrm{hour} / \mathrm{mg}$ protein for untreated and implanted mice respectively, very similar to the level reported by Ray for rat liver [8]. 


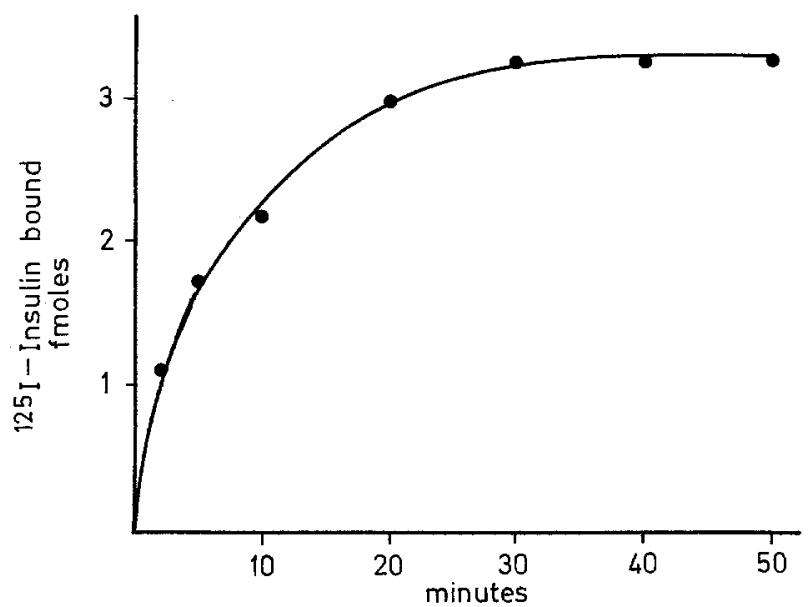

Fig. 2. Rate of binding of ${ }^{125} \mathrm{I}$-insulin to NZO mouse liver plasma membranes. Liver plasma membranes $(1.0 \mathrm{mg})$ were incubated with $1 \times 10^{-10} \mathrm{M}^{125} \mathrm{I}$-insulin in the presence and absence of unlabelled insulin $\left(2 \times 10^{-5} \mathrm{M}\right)$ in a final volume of $3.0 \mathrm{ml} \mathrm{KRP}, 1 \%$ albumin $\mathrm{pH} 7.4$ buffer. $0.3 \mathrm{ml}$ aliquots were removed from the mixture and filtered at the indicated time intervals. The results shown are from one experiment in which each point was determined in triplicate. The counts due to non-specific binding have been subtracted

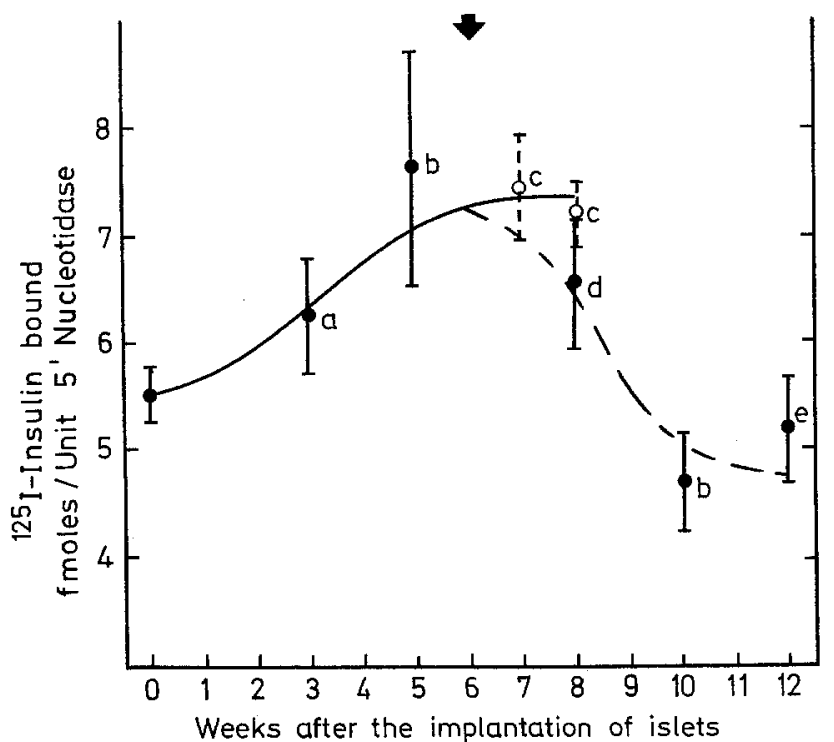

Fig. 3. The effect of implanting normal mouse islets on the binding of ${ }^{125}$-insulin to liver plasma membranes of NZO mice. The amount of ${ }^{125} \mathrm{I}$-insulin bound/unit of $5^{\prime}$ nucleotidase activity is shown at various times after the implantation of normal mouse islets into NZO mice ( $-\cdots)$. The effect of removing the islets after 6 weeks on insulin binding is shown by (----) while animals implanted for longer than 6 weeks without implant removal are shown by $(-\infty)$. The binding assays were carried out with $80-120 \mu \mathrm{g}$ of membrane protein incubated with ${ }^{125} \mathrm{I}$-insulin $1 \times 10^{-10} \mathrm{M}$ in a final volume of $0.3 \mathrm{ml}$. The results are $\pm \mathrm{S}$. D. Significance compared to the initials: points a) $p<0.05$; points b) $p<0.005$; points c) $p<$ 0.001 ; point d) $p<0.01$ and point e) N.S.

Differences between other points: 3 weeks to 5 weeks $p<0.05 .3$ weeks to 8 weeks $p<0.005$. 10 weeks to 12 weeks $p$ N.S. 8 weeks $(\longrightarrow-\infty)$ ) to 8 weeks $(-\cdots) p<0.05$

\section{The Binding of ${ }^{125}$ I-Insulin}

The binding of ${ }^{125}$ I-insulin to NZO mouse liver membranes was found to be very rapid, $50 \%$ of binding occurred by $7 \mathrm{~min}$, with equilibrium being achieved by $40 \mathrm{~min}$ as shown in Fig. 2. Experiments that required the reaction to reach equilibrium were therefore incubated for $40 \mathrm{~min}$.

The amount of ${ }^{125} \mathrm{I}$-insulin bound by the different membrane preparations was determined ar equilibrium and at a ${ }^{125} \mathrm{I}$-insulin concentration of $1 \times$ $10^{-10} \mathrm{M}$. This binding capacity has been expressed in terms of the $5^{\prime}$ nucleotidase activity of each membrane preparation and the result is shown in Fig. 3. The ${ }^{125}$ I-insulin binding was significantly increased by the 5 th week $(p<0.005)$ and this increase was maintained over the 7 th and 8 th weeks. The binding at 3 weeks showed this upward trend being marginally higher than the control binding $(p<0.05)$.

Two weeks after the removal of the implanted islets, the insulin binding was still higher than the initial level $(p<0.01)$ but lower $(p<0.05)$ than that found in the membranes from animals implanted for 8 weeks. By 6 weeks after implant removal (i.e. 12 weeks after the start of the experiment) insulin binding had returned to pre-implant levels.

The competition for binding between insulin and ${ }^{125}$ I-insulin was determined over a wide concentration range. The results for membranes from untreated NZO mice and from mice implanted for 5 weeks are shown in Fig. 4. All the membrane preparations had very similar displacement curves. The curve clearly shows that membranes from the untreated New Zealand Obese mice which bind less insulin than the 5 week implanted mice are equally sensitive to insulin displacement in the physiological range $0.4-4 \mathrm{ng} \mathrm{ml}^{-1}$ $\left(10-100 \mu \mathrm{U} \mathrm{ml}^{-1}\right)$. The affinity constants were calculated by plotting the displacement data in the form Bound/Free v. Bound described by Scatchard [15]. Curved lines were obtained and the initial slope was used to estimate the constant for the high affinity interaction. The values obtained for all membranes were in the range $1.4-4.5 \times 10^{9} \mathrm{M}^{-1}$ and there were no significant differences between the different membrane preparations.

\section{Degradation of ${ }^{125}$ I-Insulin}

When the concentration of membranes is less than $0.4 \mathrm{mg} / \mathrm{ml}$ and the ${ }^{125} \mathrm{I}$-insulin concentration is $1 \times$ $10^{-10} \mathrm{M}$ the degradation observed by both the TCA precipitation method and the gel filtration method is less than $10 \%$. The percentage of ${ }^{125}$ I-insulin remaining intact at the end of a $40 \mathrm{~min}$ incubation was $95 \%$ 

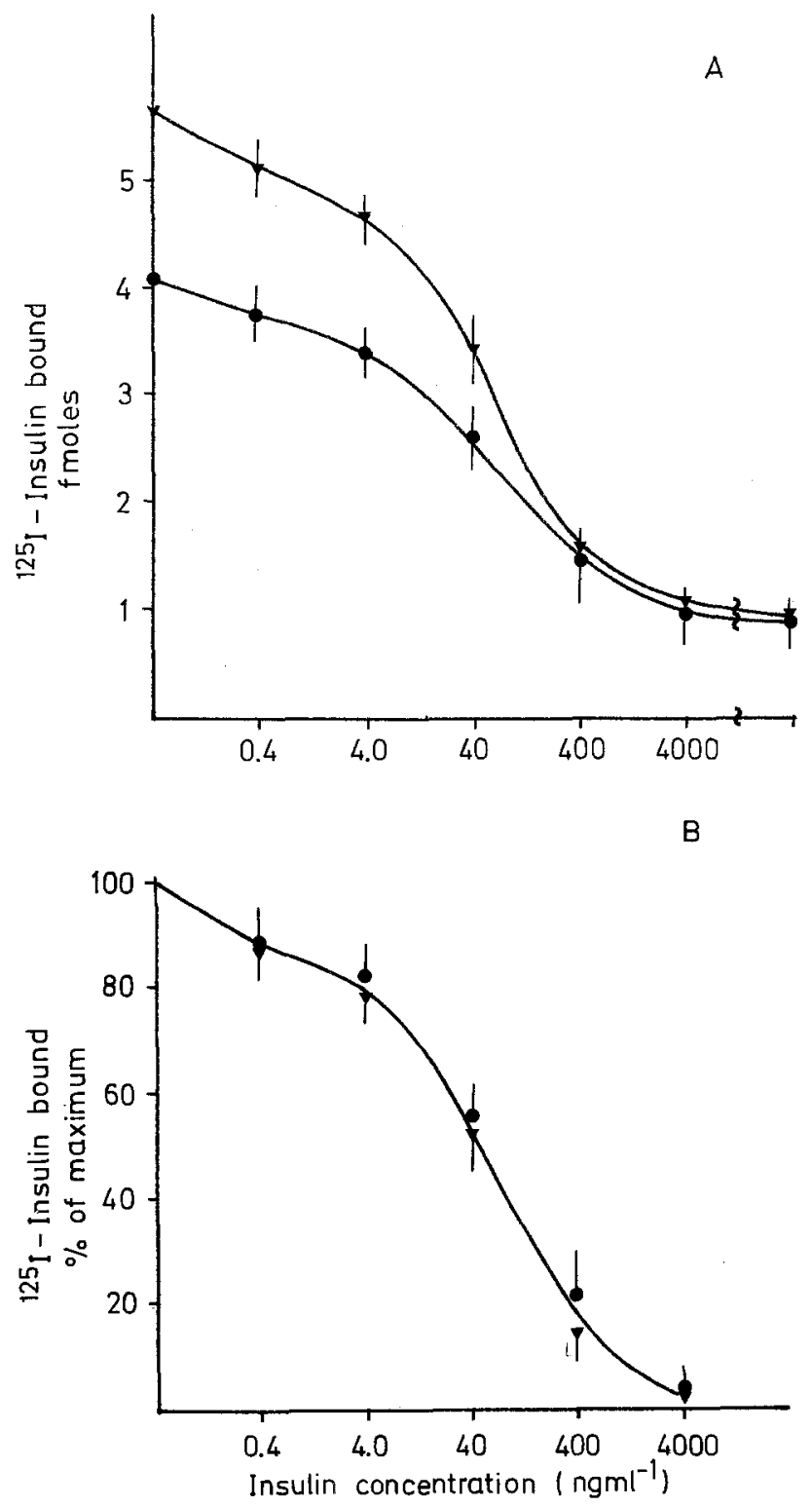

Fig. 4. The effect of insulin on the binding of ${ }^{125} \mathrm{I}$-insulin to NZO liver membranes. Liver plasma membranes $80-120 \mu \mathrm{g}$ protein were incubated with ${ }^{125} \mathrm{I}$-insulin $1 \times 10^{-10} \mathrm{M}$ in the absence of added unlabelled insulin or in the presence of unlabelled insulin at concentrations of $0.4-4,000 \mathrm{ng} / \mathrm{ml}$ in a final volume of $0.3 \mathrm{ml}$. The results are \pm S.D. a) The binding is expressed as fmoles ${ }^{125} \mathrm{I}$-insulin bound $/ 100 \mu \mathrm{g}$ of membrane protein. The non-specific binding is the bound ${ }^{125} \mathrm{I}$-insulin that is not displaced at the highest unlabelled insulin concentration $\left.\left(2 \times 10^{-5} \mathrm{M}\right) . \mathrm{b}\right)$ The binding is expressed as a percentage of the maximum binding attained in the absence of added insulin after the subtraction of the non-specific binding. The results shown are for liver membranes of NZO that had not been implanted with islets $(\boldsymbol{\nabla})$; that had been implanted with islets for 5 weeks (•)

for membranes from untreated NZO mice and $93 \%$ for membranes from NZO mice that had been implanted for 5 weeks. By gel filtration the results were

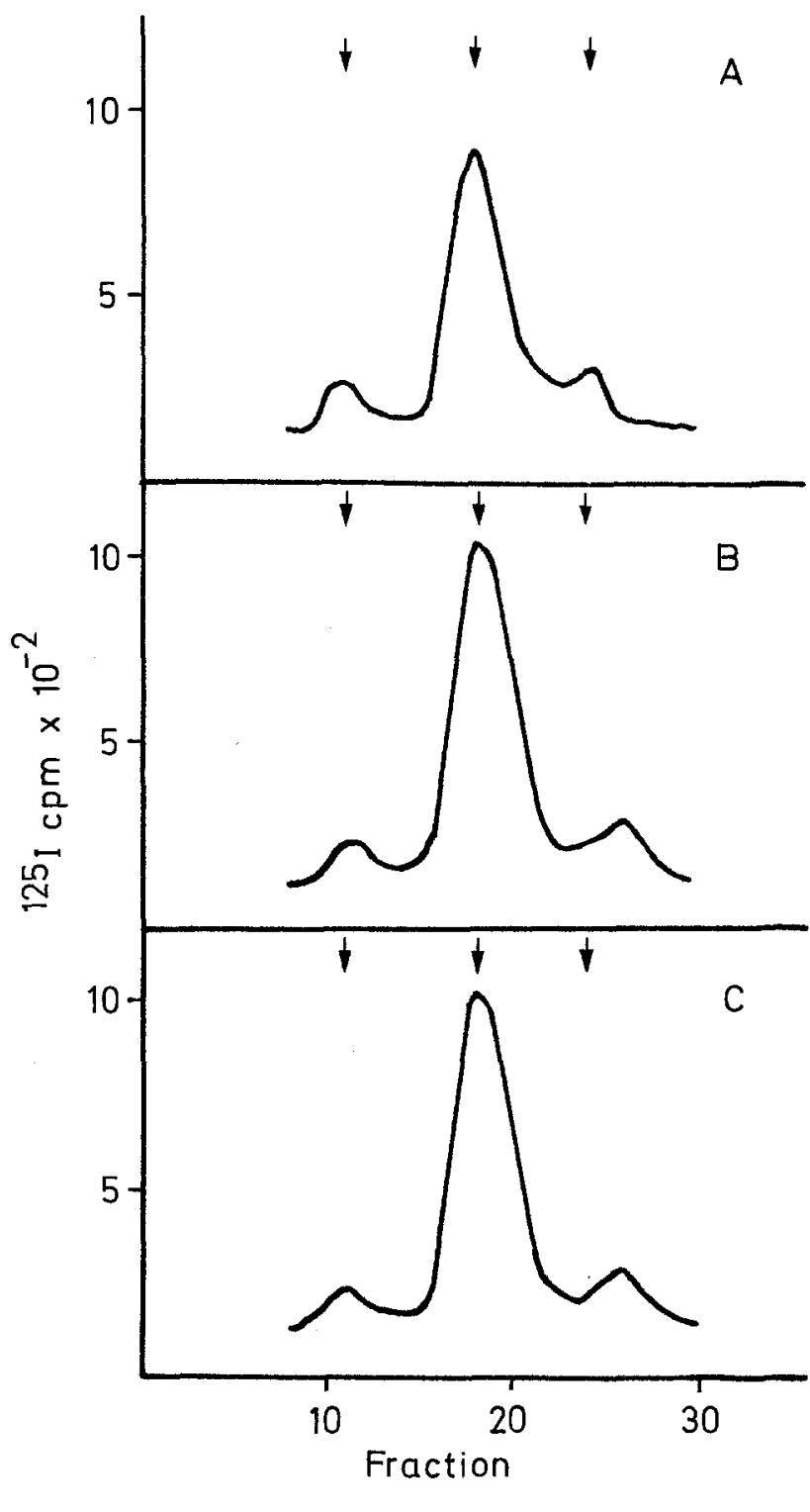

Fig. 5. The degradation of ${ }^{125} \mathrm{I}$-insulin by liver plasma membranes, shown by gel filtration on Sephadex G-50. Membranes $\left(0.4 \mathrm{mg} \mathrm{ml}^{-1}\right)$ were incubated with $1 \times 10^{-10} \mathrm{M}{ }^{125} \mathrm{I}$-insulin in KRP $1 \%$ albumin buffer for 40 minutes at $24^{\circ} \mathrm{C}$. The membranes were removed by centrifugation and $100 \mu \mathrm{l}$ of supernatant applied to a column $7 \times$ $220 \mathrm{~mm}$ of Sephadex G-50. The whole of each 15 drop fraction was counted for radioactivity. A - No membrane control. B - After incubation with membranes from untreated NZO mice. C - After incubation with membranes from NZO mice implanted with islets for 5 weeks. The arrows mark the position of the void volume and the elution volumes of insulin and salts

$94.5 \%$ and $90.5 \%$ respectively. Gel filtration always gave a slightly lower result than precipitation by TCA probably because TCA precipitates ${ }^{125} \mathrm{I}$ bound to high 
molecular weight material which appears in the void volume on gel filtration, Fig. 5. The samples incubated with membranes show a small but significant number of counts eluting after the salt peak. This is caused by small iodinated tyrosyl fragments, produced by the degradation, which are adsorbed to Sephadex.

\section{Discussion}

The purified liver plasma membrane fractions were all prepared by an identical procedure so that comparison between the binding capacity of different membrane preparations could be made. In addition, insulin binding was related to the specific activities of the membrane marker enzyme $5^{\prime}$ nucleotidase. It was found that the $5^{\prime}$ nucleotidase activities in the various preparations were similar. Two out of the eight preparations were significantly different, i.e. 7 weeks after implantation and 4 weeks after implant removal. Both these times occur well after the trends in binding capacity have been established and do not significantly affect the result. The use of a constant such as $5^{\prime}$ nucleotidase, adenylate cyclase or intact hepatocytes to express binding has been discussed by Kahn et al. [16]. They observed that higher insulin binding to liver membranes of lean compared to obese ob/ob mice was not affected by their choice of parameter. Similarly, our results would not be altered if they were expressed as insulin bound/mg membrane protein rather than per unit $5^{\prime}$ nucleotidase activity.

The effect a different rate of insulin degradation could have on the binding results has been considered. An increased insulin degradation in the untreated mice would result in a reduced ${ }^{125} \mathrm{I}$-insulin concentration in the binding assays and so the ${ }^{125} \mathrm{I}$-insulin bound would be reduced. The results we have presented show that there is very little degradation under the conditions used in our binding assay and that plasma membranes from untreated mice do not degrade insulin faster than membranes from implanted mice. The possibility that membranes from the untreated NZO mouse, with its elevated plasma insulin, are contaminated with the mouse's own insulin thereby reducing ${ }^{125} \mathrm{I}$-insulin binding is unlikely. The preparation of membranes involves very great dilution [see reference 8] which would eliminate the retention of mouse insulin. This question has been extensively discussed by Kahn [16] who injected lean mice with insulin and found that ${ }^{125}$ I-insulin binding to membranes prepared subsequently was not impaired.

In our previously reported preliminary results [4] membranes from mice implanted for 6 weeks were found to have an increased binding. In the present experiments this observation has been validated by extending the experimental period to eight weeks. Thus increased binding is seen at 5,7 and 8 weeks. Data were obtained from 2 or 3 membrane preparations for each implantation time and there was sufficient material to assay each batch of membranes at least twice. Thus the total number of observations at each time period varied from a minimum of 4 to a maximum of 7 . The increased specific binding in the implanted mice was not caused by a reduction in the amount of non-specific binding nor by any change in the affinity of the insulin receptor. The affinity constant were calculated by measuring the initial slope of a curved Scatchard plot. While this indicates the order of the affinity constant too much reliance should not be placed on the figures because, as discussed by Cuatrecasas [17] there are dangers in attempting a detailed analysis with data derived from displacement studies.

These results have confirmed our own observation in NZO mice and those of others in ob/ob mice [16, 18] that decreased insulin receptors are found in association with hyperinsulinaemia and hyperglycaemia. The dynamic nature of our model has also enabled us to extend these observations to show in vivo that the number of liver insulin receptors gradually increase when hyperinsulinaemia and hyperglycaemia are relieved and that this increase is fully reversible when both glucose and insulin levels are raised.

Insulin rather than glucose is likely to be the controller of receptor concentration. Gavin et al. [19] have shown that exposure of cultured lymphocytes to high levels of insulin causes a reduction of their insulin receptors. Moreover, insulin resistance can be found in association with islet hyperfunction without attendant hyperglycaemia [20].

3 weeks after the implantation of islets the plasma insulin had fallen by $67 \%$ of the total fall recorded but the increase in insulin receptors was only just measurable. We are thus unable to show changes in membrane binding preceding changes in circulating insulin. The insulin receptors of liver membranes, whether from implanted NZO mice or control animals, showed the same affinity for insulin when tested at physiological and/or higher concentrations. Although NZO mice have decreased numbers of insulin liver receptors, the ability of these receptors to bind insulin remains unaffected. Changes in receptor concentrations are probably secondary to changes in circulating insulin. The resultant decrease in numbers of receptors may give rise to the symptomatology of insulin resistance.

\footnotetext{
Acknowledgements. We are indebted to Mr. Ronald J. Gates for carrying out the implantations and to Mr. Keith Johnson for his expert technical assistance.
} 


\section{References}

1. Crofford, O.B., Davis, C.A.: Growth characteristics, glucose tolerance and insulin sensitivity of New Zealand Obese mice. Metabolism 14, 271-280 (1965)

2. Gates, R.J., Hunt, M.I., Smith, R., Lazarus, N.R.: Return to normal of blood glucose, plasma insulin and weight gain in New Zealand Obese mice after implantation of islets of Langerhans. Lancet 1972 II, 567-570

3. Gates, R.J., Hunt, M. I., Lazarus, N.R.: Further studies on the amelioration of the characteristics of New Zealand Obese (NZO) mice following implantation of islets of Langerhans. Diabetologia 10, 401-406 (1974)

4. Baxter, D., Gates, R.J., Lazarus, N. R.: Insulin receptor of the New Zealand Obese (NZO) mouse: changes following the implantation of islets of Langerhans. Proc. 8th Congr. Int. Diabetes Fed., Excerpta Medica Foundation Congress Series No. 280, Abstract 161 (1973)

5. Bielschowsky, M., Bielschowsky, F.: A new strain of mice with hereditary obesity. Proc. Otago Univ. Med. Sch. 31, 29-31 (1953)

6. Faulkner, D.E.: An automated microdetermination of blood glucose with the autoanalyser. The Analyst 90, 736-744 (1965)

7. Hales, C. N., Randle, P.J.: Immunoassay of insulin with insulin antibody precipitate. Lancet 1963 I, 200

8. Ray, T.K.: A modified method for the isolation of the plasma membrane from rat liver. Biochim. biophys. Acta (Amst.) 196, 1-9 (1970)

9. Lowry, O.H., Rosebrough, N.J., Farr, A.L., Randall, R.J.: Protein measurement with the Folin phenol reagent. J. biol. Chem. 193, 265-275 (1952)

10. Greenwood, F. C.: Radio-iodination of peptide hormones: procedures and problems. In: Principles of competitive protein binding assays (eds. W.D. Odell, W.H. Daughaday), pp. 288-302. Philadelphia: J. B. Lippincott Company 1971
11. Cuatrecasas, P.: Properties of insulin receptors of isolated fat cell membranes. J. biol. Chem. 246, 7265-7274 (1971)

12. Belfield, A., Goldberg, D.M.: Inhibition of the nucleotidase effect of alkaline phosphatase by $\beta$-glycerophosphate. Nature 219, 73-75 (1968)

13. Fleischer, S., Fleischer, B.: Methods in enzymology X, p. 427. New York: Academic Press 1955

14. Fiske, C.H., Subbarow, Y.: The colorimetric determination of phosphorus. J. biol. Chem. 66, 375-400 (1925)

15. Scatchard, G.: The attractions of proteins for small molecules and ions. Ann. N. Y. Acad. Sci. 51, 660-672 (1949)

16. Kahn, C. R., Neville, D. M., Jr., Roth, J.: Insulin-receptor interaction in the obese hyperglycaemic mouse. A model of insulin resistance. J. biol. Chem. 248, 244-250 (1973)

17. Cuatrecasas, $P .:$ The nature of insulin receptor interactions. In: Insulin action (ed. I. B. Fritz), pp. 137-169. London: Academic Press 1972

18. Freychet, P., Laudat, M.H., Laudat, P., Rosselin, G., Kahn, C. R., Gorden, P., Roth, J.: Impairment of insulin binding to the fat cell plasma membrane in the obese hyperglycemic mouse. FEBS Letters 25, 339-342 (1972)

19. Gavin, J.R., III, Roth, J., Neville, D.M., Jr., De Meyts, P., Buell, D.N.: Insulin dependent regulation of insulin receptor concentrations: a direct demonstration in cell culture. Proc. nat. Acad. Sci. (Wash.) 71, 84-88 (1974)

20. Perley, M., Kipnis, D.: Plasma insulin responses to glucose and tolbutamide of normal weight and obese diabetics and nondiabetic subjects. Diabetes 15, 867-874 (1966)

N.R. Lazarus, M.D.

The Wellcome Foundation Ltd.

Temple Hill

Dartford

Kent DA1 5 AH

England 